\title{
SWOT EVALUATION OF TRAINING FRAMEWORK: A REVIEW OF THE PROCESSES, STRONG POINTS AND ROADBLOCKS OF TRAINING AND DEVELOPMENT FOR THE INDIAN PRIVATE BANKS
}

\author{
Rashi Tandon \\ Research Scholar, Jayoti Vidyapeeth Womens' University, Jaipur, Rajasthan, India \\ Dr. Mini Amit Arrawatia \\ Assistant Dean, Jayoti Vidyapeeth Women's University, Jaipur, Rajasthan, India
}

\begin{abstract}
In the current era of a highly strained business environment in banking organizations encounter with transpiring challenges in form of optimization and acquisition of the human resource. Being valuable and scarce capabilities, human resources are considered as a source of tenable vying mastery. The success of a banking organization depends upon several factors; however, one of the most crucial factors that influence the organization performance is its employee. The HRM practices like Training, Team Work, Performance Appraisal, and Compensation has an imperative impact on the banks. Human resources play an integral role in achieving an innovative and high-quality servicel product. The present study through the SWOT evaluation attempts to examine and analyse the impact of all these factors and the role of training and development of private sector banking employees in India. Also to assess the present status of the employee effectiveness in discharging the roles and responsibilities in tune with the objectives of the bank. The effectiveness of the various facets of training i.e. employee's attitude towards the application of practice; training inputs; quality of training programmes and training inputs to the actual job.
\end{abstract}

Keywords: Human Resource Management Practices, HRM, SWOT, training programmes, Training, Performance Appraisal, Team Work, Employee Participation Cite this Article: Rashi Tandon and Dr. Mini Amit Arrawatia, Swot Evaluation of Training Framework: A Review of the Processes, Strong Points and Roadblocks of Training and Development for the Indian Private Banks, Journal of Management, 10 (2), 2019, pp. 36-43.

http://www.iaeme.com/JOM/issues.asp?JType=JOM\&VType=10\&IType=2 


\section{INTRODUCTION}

In efficient implementation of human resource management practices in banking sector one of the key factor to be observed is training and development. Training and development also boosts in improving an employee's performance that in turn would enhance not only their knowledge and skills in their thorough learning but also will alter employees' attitudes (Goswami, Pandey, \& Vashisht, 2017). Additionally, it is an attempt to improve the employee's performance not only in their current job but also to prepare them for an intended job as well. Hameed, Rajinikanth, \& Mohanraj, (2014) reported that employee training and development in banking sector in an activity which is desirable and also an imperative activity wherein an organization must be resourceful if it has to maintain a knowledgeable and viable workforce. Training seems to bridge the gap developed among the employees' present specifications and job requirements. Further to develop a comprehensive understanding on the issues and causes banks have opted for SWOT analysis. Private banks especially those which have been newly established in the private sector banks on the other hand have evolved aggressively by using innovative strategies and highly competitive, particularly with their strong emphasis on information technology (IT). As a result, private sector banks have made considerable progress in a very short span of time. Kumar (2005) illustrated about the organizational climate (OC) of new private sector banks and foreign banks in India to be perceived as significantly better visà-vis public sector banks. The difference was observed on leadership, motivation, interaction influence, decision making, communication, goal setting, and control process aspects of organizational climate. Moreover, recent SWOT analysis, alternatively known by SWOT matrix that is a structured planning method used to assess the strengths, weaknesses, opportunities, and threats intricately linked in a project or in a business venture. SWOT analysis is conducted with reference to a place, person, product or industry. It includes specific objectives of the project or business venture, and identifying external factors and inter factors which are advantageous and disadvantageous in procuring the objective. Albert Humphrey is the person credited for the technique, he lead a convention at the Stanford Stanford Research Institute (now SRI International) in the 1960s and 1970s using data from Fortune 500 companies (Stenfors \& Tanner, 2006). The level at which the external environment is matched with the internal environment of the firm is expressed by the concept of strategic fit. It is once that the SWOT analysis is performed, the objectives or goals are set for the organization (Osita, Onyebuchi, \& Nzekwe, 2014). First comes the strengths which is associated with characteristics of the business, banks or project that an upper hand over others. Second in line is weaknesses a characteristics that place the business, banks or project at a limiting factor relative to others. Thirdly, opportunities which are factors that state the level at which a particular project could be exploited to its advantage. Lastly, threats: is considered as a factors in the environment that could cause trouble for the business, banks or project. In order to build competencies across various sectors banks have established a strong capabilities in their training and development. Through internet-based training modules training is imparted on products and operations (Jyoti, 2017). Stumpf, Doh, \& Tymon, (2010) in their study assertively mentioned about Human Resource Management being one of the imperative determining factor in an organizational performance or efficiency. Further, special programmes on leadership development and functional training are performed in order to build knowledge as well as ability to manage at a dedicated training facility.

\section{LITERATURE REVIEW}

The service sector in India consists of a broad range of services such as water supply, road, rial, electricity and air transport, and banking among others. Banking sector is perceived to be the backbone of the service field and has also staged itself as one of the biggest employers in India. 
This section will thus account the evolutionary changes that occured in the Indian banking sector and the human resource (HR) personnel in the banking sector that assertively involved and formulation of the human resource practice and management policies in private banks are elucidated in this section.

\subsection{Relative evolutionary changes in Indian banking sector:}

In the first decade of the 18th century, banking had originated in India with The General Bank (1786) of India followed by Bank of Hindustan (1870). However, both of these banks at present are not in service, the oldest bank is the State Bank of India (SBI) subsisting in India that was established in June 1806 by the name 'The Bank of Bengal' in Calcutta. Later in the year by 1900s, banks such as Punjab National Bank (PNB) in 1895 in Lahore and Bank of India, year 1906 in Mumbai. The effect through economic reformations bought in the banking sector is now visible and is still persisting. Some of the major visible changes that occured in the functioning of banks in India were only after the government decision of liberalization, globalization and privatization. The contributory factors were new information technologies, increased competition, declining processing cost, less restrictive governmental regulations and the erosion of public and geographic boundaries have all been instrumental in India. Other banks such as Bank of Madras (1843) was established by the East India Company. All the three individuals units namely Bank of Madras, Bank of Bombay and Bank of Calcutta were called as the Presidency Banks. Later in 1865, Allahabad Bank was for the first time completely run by Indians. Further 1894 was set up in Punjab National Bank Ltd with his headquarters at Lahore. Other banks such as Bank of India, Canara Bank, Central Bank of India, Bank of Baroda, Indian Bank, and Bank of Mysore between were set up in the year 1906-1913.

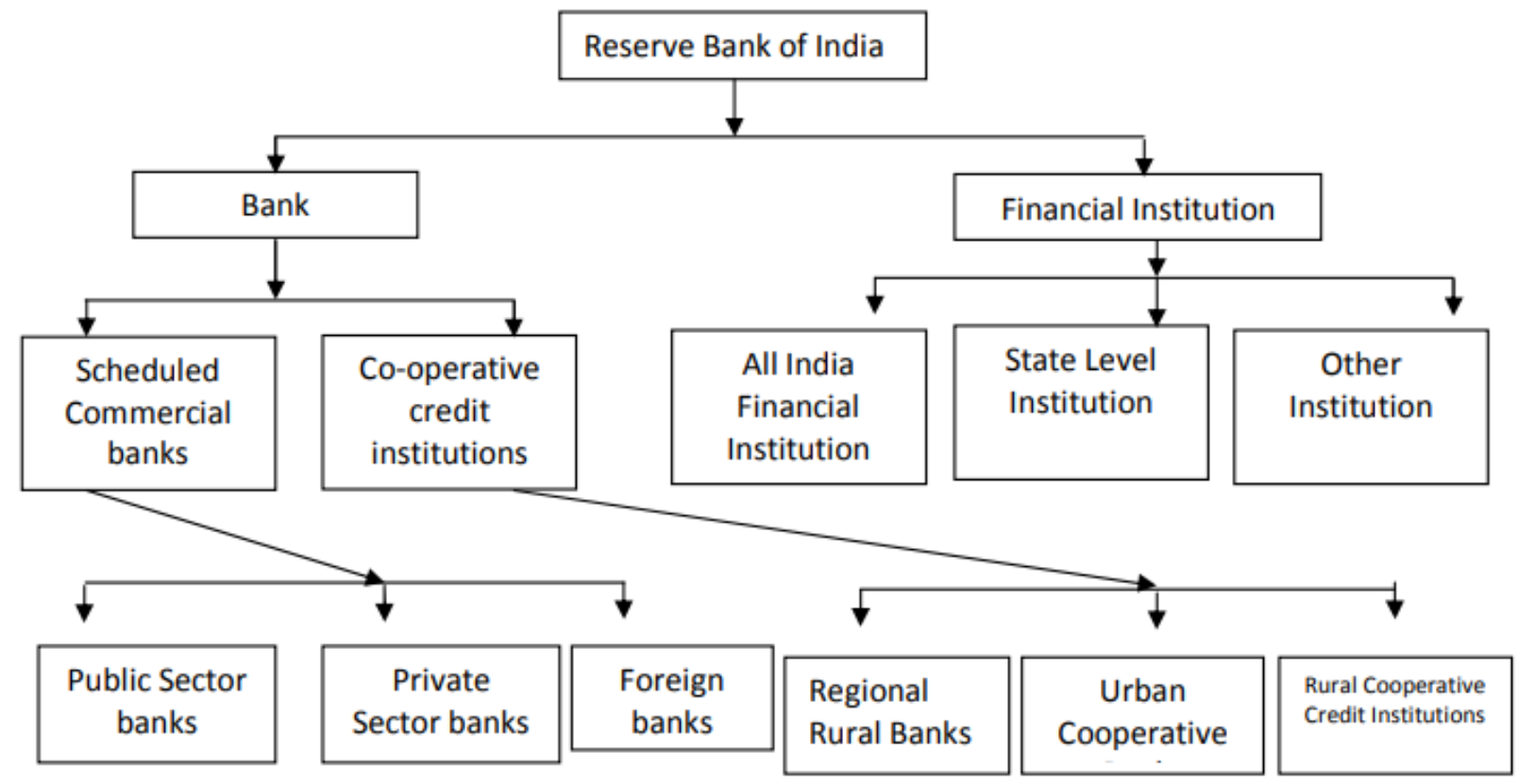

Figure. 1: Schematic diagram of banking structure in India

\section{Sources: Goyal, K. A., \& Joshi, V. (2012). Indian banking industry: Challenges and opportunities.} International Journal of Business Research and Management, 3(1), 18-28.

Further, all the presidency banks were unioned to twenty-two forms, the Imperial Bank of India in 1921, which was run by European shareholders. In April 1935 the Reserve Bank of India was established. Initially, the banking sector observed a very slow growth in their 
primitive phase prior to 1955. Nonetheless, in the period of 1913-1914 an approximate 1100 small banks emerged in India. Therefore, the Government of India started streamlining the functioning and activities of commercial banks by coming up with Banking Companies Act, 1949 which was later reformed to Banking Regulation Act 1949 as per amending Act of 1965 (Act No.23 of 1965). Extensive powers were endowed with Reserve Bank in India for the supervision of banking in India as a Central Banking Authority. Government has taken imperative steps after independence with respect to Indian Banking Sector reforms. The Imperial Bank of India was nationalized in the year 1955 and was named as "State Bank of India", to proceed as the chief agent in RBI and to account banking transactions all over the country. It was entrenched under State Bank of India Act, 1955. In the year 1960, all the seven banks forming subsidiary of State Bank of India were nationalized (Misra \& Puri, 2011). Approximately $80 \%$ of the banking segment in India by the year 1980 was under government ownership. Shah and Tyagi (2017) reported Government of India, taking major steps in order to regulate banking institutions in the country like Enactment of Banking Regulation Act (1949), Nationalisation of State Bank of India (1955), Nationalization of SBI subsidiaries (1959), Insurance cover extended to deposits (1961), Nationalisation of 14 major Banks (1969), Creation of credit guarantee corporation (1971), Creation of regional rural banks (1975), and Nationalisation of seven banks with deposits over 200 Crores (1980).

\subsection{Human Resource Practice and Management Policies in private banks:}

Lee, Pak, Kim and Li (2016) examined the relationships between human resource management systems on employee proactivity and group innovation. Significant correlations was found on proactivity to innovative reformations brought in the workplace. Various other scholars also addressed on the correlation among human resource management (HRM), work climate, and organizational performance in the branch of retail banking network (Gelade \& Ivery, 2003; Cooper, Wang, Bartram, \& Cooke, 2019). Noteworthy association was observed among business performance, human resource practices, and work climate. HRM was the common dependent factor that showed correlation between performance of employee and work environment, also the results obtained from the data were in accordance with the mediation model wherein the effects of HRM practices on business performance are not completely mediated by work environment. The essential factor perceived to bring out the best in a man is assumed to be tailored by human resource development (HRD). HRD is the exercise that increases the capacity of human resources through the development. Work done by individuals with the aim to develop themselves, managers perform work to support development of others and the HRD does it to create an overall development tools for an organization. It address value to teams, individuals and the organization as a human system. In context to a bigger scenario, HRD refers to enabling people and empowering them to use their work energy for development of the organization to which they belong as well as to the society (Shah, \& Tyagi, 2017). There has been a shift from slave relationship and traditional master to the modern trusteeship system (wherein employees and employers are considered as partners investing their labor and wealth respectively) and from traditional salary administration to the new Human Resource System (HRS). Human resources being a part of an organization, HRS is perceived to be the subsystem of the larger system, thus Human Resource Development and an organization is the centerpoint in HRS and most vital for the organizational advancement. Human Resource Development includes both the development of the people and development of an organization. Banking industry has thus been observed to transforme vigorously in the past ten years, moving from customer service-oriented and transactional to an elevating aggressive environment wherein top priority is given to revenue in competition. Decrease in revenue is at times also associated with diminishing employee morale (Shah, \& Tyagi, 2017). A substantial amount of time, effort and money by top level executives and HR departments. Mitchell, Holtom, Lee and 
Graske (2001) reported in their study about people often leaving for reasons unrelated to their jobs. Further, there were many cases wherein unexpected events or shocks as the proposed reason. Oftenly the employees are perceived to stay due to the attachments and their sense of fit, both in their community and on the job. Technology is also one of the factors that has practical application of science to industry or commerce. A collection of changes in activities requiring different skills ranging from employee relations (highly qualitative) to benefit administration (highly quantitative) and compensation are covered in human resources tasks. Walker (2001) reported about how HR technology should focus on strategic alignment, efficiency, and business intelligence. It must change the work performed by HR personnel, by improving service level, allowing more time to work of higher value, and reducing their costs. Lewi (2003) had also addressed about high involvement practices resulting in the of return on capital employed, revenue growth, improvement on market value, product/service quality, even organizational survival and revenue-per-employee rate, productivity. Further, HR using the technology has assisted in improving the business performances. Sartain (2005) reported that HR is obligated to bring the voice of customers to inside the organisation and accomplishing that, so the management people could empower HR to reflect the customer's value proposition. Jyoti (2017) addressed on fashion of banks to be able to capture everything, thereby proving helps them do better career and planning senior management better data for performance evaluations. Additionally, the automation actions such as e-mail notifications, vacation hour balance and warnings assists banks in complete profile for each employee. Currently the existing comprehensive reporting capabilities save enormous amount of staff time and permits bank to handle profiles, training, skill sets and integrate them with the payroll system.

\subsection{Conceptual framework:}

The Indian banking sector has a relatively large amount of banks, some amongst them are suboptimal in scale and size of the operation. Alignment with global developments in banking supervision is a focus are in banking supervision for both banks and regulators. A high level of sophistication is required on information systems, risk management and technology in the new international capital norms that may pose a challenge for many participants in the Indian banking sector. Nowadays, banks are using the various channels of banking such as providing ATM machines for the quick withdrawal of money from all banks; for the customer's help majorly banks that are also being proving call centers; proving banking customers with online banking facility for the transactions of money from different place to any other place through the internet; and use of mobile banking that is provided by the banks for banking transactions. Further, Singh, Yadav, \& Paliwal (2017) also mentioned about many banks being opened which had branches of their bank in rural areas too. Singh and Kohli (2006) under their findings had recently said about SWOT analysis of private banks point out about the presence of divergence from traditional banks (public sector banks and old private sector banks) in the new private sector banks and their strength reclines in the following areas:

- Majority of the branches of private sector banks acquire support core banking solutions and have fully computerized organization.

- There is an efficient payment system supported in the private sector banks and the majority of the banks are unconfined from the bureaucratic work environment.

- Dissimulated to their public sector counterparts, maintenance of operational efficiency is at the highest degree, as private sector banks provide a regularized working environment to their employees. 
- There is an absence of bureaucratic environment in the private sector banks as a result of which they enjoy a high level of autonomy that aids in quick decision making.

- Along with higher automation to their work, private sector banks are more prevalent at innovating new customized products and services, therefore a high on customer satisfaction can be achieved.

- more responsive organizational structure as compared to public sector banks is observed in private sector banks that result in better addressing customer problems.

- Private sector banks offer full computerization, cost-effective services such as electronic fund transfer, automated teller machines, Internet banking with much ease.

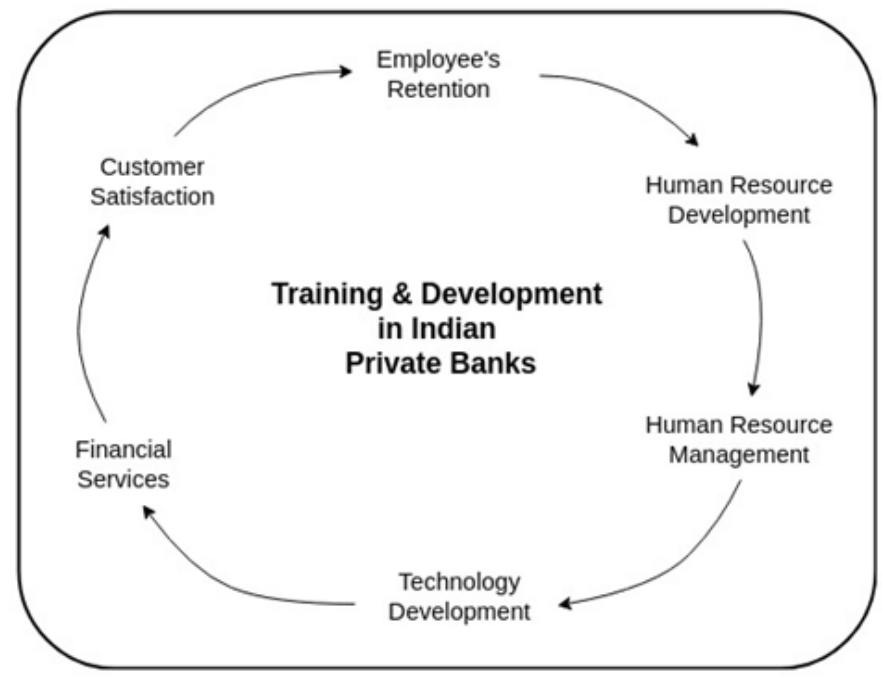

Figure. 2: Conceptual framework of SWOT evaluation on training and development in Indian private banks.

Thus, now-a-day employee training is fetching a necessity for every organization. Employees are endowed to different responsibilities and roles in the banks. Therefore, training enables them to carry out these responsibilities and roles methodically and also learn new contrivance, which will prepare them to take up much greater responsibilities in the upcoming time period. Further, the existing practices of the various aspects of the effectiveness of training and its program in selected private and public sector banks in India. Various academicians and scholars have discussed on the HRM practices, such as Katou (2008) reported in their study about assessing the impact of HRM practices on organizational performance in the manufacturing sector of Greece. The results indicated that the relationship between organizational performance is partially mediated through HRM outcomes (skills, attitudes, behaviour), and HRM practices (development and sourcing, compensation and incentives, job design and involvement) and it is influenced by business strategies (innovation, cost, quality). The study concluded that HRM practices are associated with business strategies will affect organizational performance through HRM outcomes. Iqbal, Arif \& Abbas (2011) illustrated in their research about a comparison done on the HRM practices of Pakistan among executives in both public and private universities. The study established that there was a significant difference in HRM practices in private and public universities. HRM practices such as job definition, compensation, training and development, teamwork and employees participation were better in the public universities than private universities. All these findings helped comprehend about the imperative need of training and development in the employees' that would, in turn, reduce the employee retention in the banking sector, especially at private banks through their HRM 
Swot Evaluation of Training Framework: A Review of the Processes, Strong Points and Roadblocks of Training and Development for the Indian Private Banks

and HRD policies and management strategies for achieving the ultimate goal that is customer satisfaction.

\section{FINDINGS AND DISCUSSION:}

The studies that affirmed that the banking sector needs training in order to development of an employee and also improves an employee's knowledge and skills at a task. Further, investigated that in order to attain an objective, it is a sequence of opportunities and experiences which was designed to modify an employee's attitude. Also, banks had only concentrated their operations just in developing cities and town and to attract the attention of banks with reasonable capabilities of growth has also been failed in the semi and rural-urban centres (Kohli, 1999). In industry, the target of a training system provides banking education to the employees helps in uplifting the private sector banks in India. The programmes and methodologies that the organization should take into account while formulating training and development ais ought to be formulated on an organization's needs and staff. Moreover, the growth of an organization primarily targets the training and development to developing competencies like; conceptual and technical. Also, future private banking organizations need to make a massive investment in the programmes related to training and development in India. Although challenges and difficulties are erupting in the training and development department of both public sector banks and private sector banks yet from the above examination could theorize that training of private banks is superior to public sector banks.

\section{CONCLUSION}

Human Resource Department should work as a philosophy of values and culture of the banks. Essentially, the employees that are engaged with performance levels will be higher, they would sell harder, provide better service, productivity would be higher, further would manufacture lesser defects, enriched quality, and most importantly the safely records too will be improved as employee engagement is a barometer that determines the association of an employee with his organization. However, an associated and engaged employee is always a productive employee. The utilization of all other resources directly determined on the efficient utilization of human resources. Every organization needs to have well-trained and experienced people to perform the activities that have to be done. As jobs have become more complex in the banking sector, the importance of employee training has increased. In a rapidly changing society, employee training is not only an activity that is desirable but also an activity that an organization must commit resources to if it is to maintain a viable and knowledgeable workforce. Owing to the changing banking environment, the HR department should care for appropriate response in equipping people who have to perform in the new environment. In this study, when the effectiveness of training increases it directly has a positive influence on growth \& result of the banks. So training and development programmes in private banks of India is effective.

\section{REFERENCE:}

[1] Cooper, B., Wang, J., Bartram, T., \& Cooke, F. L, Well-being-oriented human resource management practices and employee performance in the Chinese banking sector: The role of social climate and resilience. Human Resource Management, 2019

[2] Essays, UK, Training and Development in ICICI Bank. Retrieved from https://www.ukessays.com/essays/management/training-and-development-in-icici-bankmanagement-essay.php?vref=1, 2018

[3] Gelade, G. A., \& Ivery, M, The impact of human resource management and work climate on organizational performance. Personnel psychology, 56(2), 2003, pp 383-404. 
[4] Goswami, R., Pandey, M., \& Vashisht, A, Training and Development Practices in Public and Private sector banks: A Comparative Study. IJARIIE-ISSN(O)-2395-4396, 3(3), 2017

[5] Goyal, K. A., \& Joshi, V, Indian banking industry: Challenges and opportunities. International Journal of Business Research and Management, 3(1), 2012, p 18-28.

[6] Hameed, D. S. S., Rajinikanth, J., \& Mohanraj, P, A Conceptual Study on Training and Development Programs of Bank Employees. International Journal of Advance Research in Computer Science and Management Studies, 2(5), 2014

[7] Humphrey, A, SWOT analysis for management consulting. SRI alumni Newsletter, 1, 2005, pp 7-8.

[8] Iqbal, M. Z., Arif, M. I., \& Abbas, F, HRM Practices in Public and Private Universities of Pakistan: A Comparative Study. International Education Studies, 4(4), 2011, pp 215-222.

[9] Jyoti, Impact of Training and Development with Reference to Banking Sector in India. International Journal of Business Administration and Management. 7(1), 2017

[10] Kamath, K. V., Kohli, S. S., Shenoy, P. S., Kumar, R., Nayak, R. M., Kuppuswamy, P. T., \& Ravichandran, N, Indian banking sector: Challenges and opportunities. Vikalpa, 28(3), 2003, pp 83-100.

[11] Katou, A. A, measuring the impact of HRM on organizational performance. Journal of Industrial Engineering and Management (JIEM), 1(2), 2008, pp 119-142.

[12] Kohli, R, Rural Bank Branches and financial reform. Economic and Political Weekly, 1999, pp 169-174.

[13] Kumar, S, A comparative study of role clarity and work locus of control in banks. Bombay Psychologist, 20, 2005, pp 14-19.

[14] Lee, H. W., Pak, J., Kim, S., \& Li, L. Z, Effects of human resource management systems on employee proactivity and group innovation. Journal of Management, 45(2), 2019, pp 819-846.

[15] Lewin, D, Human Resource Management and Business Performance in: M. Effron, R. Gandossy and M. Goldsmith, Eds., Human Resources in the 21st Century, John Wiley \& Sons, Hoboken., 2003

[16] Misra, S. K., \& Puri, V. K, Indian economy Himalaya Publishing House, 2011, p 174

[17] Mitchell, T R., Holtom, B. C., Lee, T. W. and Graske, T, How to Keep Your Best Employees: Developing an Effective Retention Policy. The Academy of Management Executive, 15(4), 2001, pp 96-109.

[18] Osita, I. C., Onyebuchi, I. R., \& Nzekwe, J, Organization's stability and productivity: the role of SWOT analysis an acronym for strength, weakness, opportunities and threat. International Journal of Innovative and Applied Research, 2(9), 2014, pp 23-32.

[19] Sartain, L, Branding from Inside Out: HR's Role as Brand Builder in: M. Losey, S. Meisinger and D. Ulrich, Eds., The Future of Human Resource Management: 64 Thought Leaders Explore the Critical HR Issues of Today and Tomorrow, John Wiley \& Sons, Hoboken, 2005

[20] Shah, S. \& Tyagi, A, HR Challenges and Opportunities in Banking Sector. International Journal of Engineering Technology Science and Research.4(7), 2017

[21] Singh, B., Yadav, P., \& Paliwal, V, Psychosocial Study of Selected Public And Private Sector Bank Employees. IOSR Journal of Business and Management. 19(12), 2017

[22] Singh, D., \& Kohli, G, Evaluation of private sector banks in India: A SWOT analysis. Journal of Management Research, 6(2), 2006, pp 84.

[23] Stenfors, S., \& Tanner, L, High level decision support in companies: where is the support for creativity and innovation. Creativity and Innovation in Decision Making and Decision Support, 1, 2006, pp 215-235.

[24] Stumpf, S. A., Doh, J. P., \& Tymon Jr, W. G, The strength of HR practices in India and their effects on employee career success, performance, and potential. Human Resource Management: Published in Cooperation with the School of Business Administration, The University of Michigan and in alliance with the Society of Human Resources Management, 49(3), 2010, pp 353-375.

[25] Walker, A. J, Web-based human resources. McGraw-Hill Professional, 2001 